\title{
Early Modern Business Diplomacy: an Appraisal
}

\author{
Cátia Antunes \\ Leiden University, Netherlands \\ c.a.p.antunes@hum.leidenuniv.nl
}

Jennifer Kesteleyn, Shaun Riordan and Huub Ruël define business diplomacy as "an approach to geopolitical and non-commercial risk management that is based on the practices and mindset of diplomats." In this definition, firms take "diplomat-like" actions in seeking to accommodate, avoid and manage external risks to the entrepreneurial activity itself. In this sense, the authors make a clear distinction between business diplomacy and current definitions of economic diplomacy, which can be summarized as actions taken by national governments to support and advance the competitive advantage of the firms these governments support. ${ }^{2}$ Even if the definition of business diplomacy is, at times, confused with a multitude of concepts like corporate diplomacy, public affairs, corporate social responsibility or public relations, Kesteleyn, Riordan and Ruël insist that "The key distinction of business diplomacy ... is not the actor, but the diplomatic mindset, which seeks to place geopolitical risk management within a coherent and long-term strategic context."3

While the conceptual framework and distinctions proposed by experts in contemporary diplomacy and international relations do not play a role in diplomatic studies regarding the Early Modern period, the absence of this framework does not necessarily mean that Early Modern historians are oblivious to matters concerning business and economic diplomacy as understood for the twentieth and twenty-first centuries. On the contrary, both concepts appear prominently in historiography pertaining to the chronology encompassed by the sixteenth to the eighteenth centuries, albeit concerning specific forms of diplomacy, particular firms and very specific geographical spaces.

1 Kesteleyn, J., S. Riordan, and H.J. Ruël. "Introduction: Business Diplomacy." The Hague Journal of Diplomacy 9 (2014), 303.

2 Okano-Heijmans, M. "Conceptualizing Economic Diplomacy: The Crossroads of International Relations, Economics, IPE and Diplomatic Studies." In Economic Diplomacy: Economic and Political Perspectives, eds. P.A.G. van Bergeijk, M. Okano-Heijmans, and J. Melissen (Leiden: Martinus Nijhoff, 2011), 17.

3 Kesteleyn, J., S. Riordan, and H.J. Ruël, “Introduction,” 304. 
The distinction between economic diplomacy and business diplomacy resides in two elements. The first of these elements relates to the actor initiating the action of diplomacy. In the case of economic diplomacy that role has been reserved for the state, while in the case of business diplomacy it has been deferred to the firm or to agents external to the firm but working on its behalf. The second element relates to the diplomatic goals to be attained. While economic diplomacy focuses on brokerage between states to negotiate the best possible institutional framework for national firms engaged in a specific market, business diplomacy is aimed at managing and preferably reducing corporate risk where firms operate in weak institutional environments or where security and access to local institutions are not guaranteed. When translating such distinctions (diplomatic actors and diplomatic goals) to the Early Modern period, certain specific examples come to mind.

Early Modern economic diplomacy, enacted by the state or by institutions to whom the state deferred sovereignty, can be best studied through the analysis of diplomatic agreements, treaties and alliances, as much in Europe as in Africa, the Americas and Asia. For territories outside Europe, the roles played by colonial governors, chartered commercial and joint stock companies, and religious orders were paramount in delineating the boundaries of economic engagement for all entrepreneurial activities, whether led by firms or through other entrepreneurial forms (plantations, refineries, general agricultural exploitation or mining). In these cases, and contrary to what can be observed in the contemporary period, the state played a direct, very succinct and geographically constrained role in ensuring specific protection for entrepreneurs who were subject to its king or republic in a specific market. To a great extent, this was a role played by multiple actors, all withholding a specific adjudication of sovereignty in order to negotiate their entrepreneurial certainties in host societies.

The difference between economic diplomacy directly sponsored by the Early Modern state and that pursued by the state's sovereign representatives resulted in differing diplomatic outcomes. Direct intervention, mostly in Europe, usually ensured a general institutional regime for all subjects of that particular state in a specific host society. Arrangements on tariffs, access to specific markets and permission to enter specific ports with one's own fleet or goods created a level playing field for all traders and skippers operating in a specific market and all subjects of a specific king or republic. ${ }^{4}$

4 Stapelbroek, K.H., and A. Alimento, The Politics of Commercial Treaties in the Eighteenth Century Balance of Power, Balance of Trade (Basingstoke: Palgrave Macmillan, 2017); Walter, R. "Economic Relations Between Europe and the World: Dependence and Interdependence." 
Economic diplomacy pursued by sovereign representatives of the Early Modern state, by contrast, and particularly outside Europe, produced a very different type of diplomatic arrangement as many of the treaties between colonial institutions and local polities resulted in regimes of exception through the provision of privileges or exclusive access to markets or resources, or security to engage with specific markets. In this case, privileges granted to the Dutch and English East India Companies or the Society of Jesus were aimed mostly at excluding other Europeans from the portrayed local privilege, rather than at creating a level playing field for all entrepreneurial initiatives on an equal footing. ${ }^{5}$ This particularity cannot be understood outside the social premises characterizing Early Modern societies that were typified not by equality for all, but rather by equality for a specific, pre-defined group to the exclusion of all others. Early Modern societies were thus populated by regimes of multiple exclusion or privilege that existed in parallel within the same society and under the same sovereign. This inherently corporatist society not only excelled at engaging and enabling economic diplomacy, but it was actually a phenomenon that fit well within the societal practices of the time. ${ }^{6}$

Furthermore, economic diplomacy, initiated by the state or by representatives of its sovereignty, was essential in an Early Modern world where mercantilism in Europe and regimes of economic monopsony, monopoly and exclusive

European History Online (2012), http://ieg-ego.eu/en/threads/europe-and-the-world/economic-relations/rolf-walter-economic-relations-between-europe-and-the-world (accessed 17 December 2019); Stapelbroek, K.H., ed. Trade and War: The Neutrality of Commerce in the Inter-State System (Helsinki: University of Helsinki - Helsinki Collegium for Advanced Studies 2011); Fisher, H.E.S. The Portugal Trade: A Study of Anglo-Portuguese Commerce, 1700-1770 (London: Methuen \& CO/Barnes and Nobles New York, 1971); Francis, A.D. The Methuens and Portugal, 1691-1708 (Cambridge: Cambridge University Press, 1966); Scelle, G. La traite negrière aux Indes de Castille. Contracts et traités d'Asiento (Paris: L. Larose \& L. Tenin, 1906).

5 Smith, E. “The Global Interest of London's Commercial Community, 1599-1625: Investment in the East India Company." The Economic History Review 71 (4) (2018), 1118-46; Serrão, J.V., B. Direito, E. Rodrigues, and S.M. Miranda, eds. Property Rights, Land and Territory in the European Overseas Empires (Lisbon: CEHC-IUL 2014); Pettigrew, W.A. Freedom's Debt: The Royal African Company and the Politics of the Atlantic Slave Trade, 1672-1752 (Chapel Hill: Omohundro Institute and University of North Carolina Press, 2013); Stern, P. The Company-State: Corporate Sovereignty and the Early Modern Foundations of the British Empire in India (New York: Oxford University Press, 2011); Brockey, L. Journey to the East: The Jesuit Mission to China, 1579-1724 (Cambridge, MA: Harvard University Press, 2007); Gaastra, F.S. Bewind en beleid bij de voc, 1672-1702 (Zutphen, 1989); Serrão et al., Property Rights.

6 Van Ittersum, M.J. "Global Constitutionalism in the Early Modern Period: The Role of Empires, Treaties and Natural Law." In Handbook on Global Constitutionalism, eds. A.F. Lang and A. Wiener (London: Edgar Elgar Publishing, 2017), 47-59; Pettigrew, W.A. "Corporate Constitutionalism and the Dialogue Between the Global and the Local in Seventeenth-Century English History." Itinerario 39 (3) (2015), 487-507; Mousnier, R. Les institutions de la France sous la monarchie absolue 1598-1789 (Paris: Presses universitaires de France, 1974). 
rights co-existed in attempts to define regimes of privileged access to resources, capital, labor and information. Entrepreneurs or firms not holding deferred sovereignty or who were not protected by the results of economic diplomacy were left to their own devices in pursuing the three elements of protection, advantage and privilege that were essential for managing risk, decreasing possible transaction costs and increasing the level of predictability in their business activities as a whole. This was equally important for firms with only one comptoir in a particular city as for firms with several comptoirs and with stakes in partnerships across Europe or on other continents.

Business diplomacy was the channel through which the diplomatic agency of Early Modern firms and entrepreneurs took place. The three specific mechanisms of practicing business diplomacy at the time, as described below, had in common their heavy dependence on personal knowledge of and adaptability to the guest society, their accessibility to power brokers in specific sites of government and governance, and their enlarged networks of business contacts willing to provide social and economic support to their entrepreneurial endeavors.

The first mechanism of business diplomacy at the disposal of Early Modern firms included a diverse panoply of petitions. These were often destined for jurisdictional holders who could and did intervene in matters of economic life. Kings, municipal councils, noblemen, archbishops, bishops and urban institutions such as guilds and brotherhoods were often approached by specific entrepreneurs, individually or collectively, in an effort to obtain economic protection, fiscal advantages or exceptional rulings on the use of infrastructures (waterways, harbors, bridges, warehouses and the like), on access to specific markets, on management or allocation of labor or on imports or exports of specific goods and services. Petitions, although professionalized instruments used by power brokers (including clerks, lawyers, notaries and scribes) in the name of specific firms, were often cheap and thus accessible even to midranging entrepreneurs such as shopkeepers, peddlers and transient traders. ${ }^{7}$

The second instrument of business diplomacy deployed by Early Modern firms involved contractualizing specific, usually financial, privileges with the

7 Van den Tol, J. "Lobbying in Company: Mechanisms of Political Decision-Making and Economic Interests in the History of Dutch Brazil, 1621-1656" unpublished PhD dissertation (Leiden University, 2018); Fontaine, L. The Moral Economy: Poverty, Credit and Trust in Early Modern Europe (Cambridge: Cambridge University Press, 2014); Vermeesch, G. "Professional Lobbying in Eighteenth-Century Brussels: The Role of Agents in Petitions to the Central Government Institutions in the Habsburg Netherlands." Journal of Early Modern History 16 (2) (2012), 95-119; Van Nierop, H.F.K. "Private Interests, Public Policies: Petitions in the Dutch Republic." In The Public and the Private in Dutch Culture of the Golden Age, eds. A.K. Wheelock and A. Seeff (London: Associated University Presses, 2000), 33-39. 
central state. In Western Europe, this contractualization translated into domestic tax farming, personal loans to kings, heavy participation in public debt and privileged investments in financial services such as insurance and mortgages. While this contractualization was common throughout Europe, local entrepreneurs, especially those that were subjects of the king in question, were in a privileged position to bid for and attain these contracts. In certain circumstances, however, foreign investors, especially those directly or peripherally connected with a specific "merchant nation," were also able to compete on an equal footing with local investors. Rather than being automatic, this equality was often the result of lengthy negotiations in which matters of war and peace, economic advantage and mutuality, and reciprocity of exchanges were codified. Contrary to the petitions, this specific type of business diplomacy was individualistic and generally privileged individual firms and their partners. ${ }^{8}$

The third and final mechanism of Early Modern business diplomacy, although conducted independently, was often possible only in conjunction with one of the other two. Early Modern entrepreneurs were often attracted to the exotic products and the wealth that could be extracted from European colonial domains. With the exception of the Dutch Republic, the overall policies of mercantilism in most European countries, which were heavily regulated through monopolies, exclusive and privileged rights, and colonial contracts, made it generally very difficult for individual firms to tap into the colonial resources of Western European countries. At the same time, central states faced acute challenges in exploiting their own colonial resources since they were often plagued by inefficient forms of financing, low demographic stocks and a general difficulty in asserting authority away from their European territorial power bases, while often also being constrained by diplomatic agreements intended to achieve peace in Europe, often disturbing competition overseas. These challenges were particularly acute where states lacked cheap local capital for investment or entrepreneurs willing and able to efficiently exploit the overseas resources. These gaps were filled, usually through a system of public auction, by non-local entrepreneurs who were contracted under various colonial contracts to enable the extraction of colonial agro-industrial products, the management of labor and the extraction of fiscal and financial rents, often on behalf of a polity. These contracts personified, on the one hand, the firm's diplomatic and entrepreneurial capacity to incorporate diplomat-like attributes

8 Drelichman, M., and H-J. Voth. "Lending to the Borrower From Hell: Debt and Default in the Age of Philip II." The Economic Journal 121 (2018), 1205-27; Álvarez Nogal, C., and C. Chamley. "Debt Policy Under Constraints Between Philip II, the Cortes and Genoese Bankers." Economic History Review 67 (1) (2014), 192-213; Häberlein, M. The Fuggers of Augsburg: Pursuing Wealth and Honor in Renaissance Germany (Philadelphia: University of Virginia Press, 2012). 
to attain social and capital gains, but at the same time, and interchangeably, personified the individual transference of the state's sovereignty to a firm, especially with regard to the extracting and re-distributing of fiscal rents. In those cases, firms not only behaved in a diplomat-like manner, but also became part of the state they served through being the bearers of that state's sovereignty overseas. ${ }^{9}$

Business diplomacy in the Early Modern world also posed challenges for the firm itself. Contrary to contemporary firms, Early Modern businesses were far from international organizations able to rely on a well-established and wellgoverned bureaucratic body. Instead, Early Modern firms usually had only a few partners and one or two clerks, normally all residing in the same city. As far as business activities deployed over long distances were concerned, the firm relied mostly on a network of agents and representatives, more often than not loosely connected to the partners or the firm itself. ${ }^{10}$ In this context, the firm depended on two specific types of business diplomacy: one at the core and one at the periphery.

At the core, partners of the firm and, at times, clerks assumed responsibility for mediating and lobbying for the firm's interests with local, regional and national government bodies. In this negotiating context, the diplomatic agency of partners and clerks depended on their capacity to penetrate, integrate or assimilate with local networks of power. By petitioning authorities or putting themselves in the position of serving the king in any way possible, these individuals created channels for accessing power and successfully conducting business diplomacy. With their success in business diplomacy increasing towards the end of the seventeenth century and throughout the eighteenth century, especially reflected in the growing numbers of firms involved in Atlantic business ventures, partners in these firms accumulated business acumen through official diplomatic representation channels, usually known as

9 Miranda, S.M. "Risk and Failure in Tax Farming: De Bruijn \& Cloots of Lisbon and the Portuguese Tobacco Monopoly, 1722-1727." Itinerario 43 (1) (2019), 122-45; Klooster, W. "Slavenvaart op Spaanse kusten: de Nederlandse slavenhandel met Spaanse Amerika, 1648-1701." Tijdschrift voor Zeegeschiedenis 16 (2) (1997), 121-40; Wright, I.A. "The Coymans Asiento, 1685-1689." Bijdragen voor Vaderlandse Geschiedenis en Oudheidkunde 6 (1924), $23-62$.

10 Gelderblom, O., and F. Trivellato. "The Business History of the Preindustrial World: Towards a Comparative Historical Analysis." Business History 61 (2) (2019), 225-59; Greif, A. "The Study of Organizations and Evolving Organizational Forms Through History: Reflections from the Late Medieval Family Firm." Industrial and Corporate Change 5 (2) (1996), 473-501; Greif, A. "Cultural Beliefs and the Organization of Society in a Historical and Theoretical Reflection on Collectivism and Individualist Societies." Journal of Political Economy 102 (5) (1994), 912-50. 
consuls. ${ }^{11}$ Over time, these consuls, albeit particularly efficient in advancing the interests of their own firms, also started developing the diplomatic skills and services that culminated, in the nineteenth century, in a broad network of consuls being established around the world. But while the diplomatic tasks of consuls increased, the core of their function essentially remained business. ${ }^{12}$ The entanglement of business and diplomacy lived forth through the nineteenth and well into the twentieth century.

Meanwhile at the periphery, agents and business representatives of European firms were forced into diplomat-like exchanges to achieve the goals set by the main comptoir in Europe. In geopolitical contexts where European societies and institutions did not dominate, such as in Africa, Asia and the Pacific, agents were forced into broad negotiations in order to gain access to specific resources, entrance to particular markets, permission to produce or exchange diverse goods and services, or simply the right to operate in a production or consumption market. Even though peripheral, these diplomatic business agents were of the essence for the firm, especially where the latter's core business depended on long-distance, cross-cultural exchanges. At the same time, and although primarily serving the goals and business interests of the firm, these power brokers advanced the geopolitical goals and interests of the European states themselves.

These general considerations regarding the Early Modern period demonstrate that although the concepts of economic and business diplomacy have been alien concepts to Early Modern historians, there does exist a broad literature on these phenomena under the guise of other historiographical conceptual parameters. What that literature proves is the existence of economic and business diplomatic practices between the sixteenth and eighteenth centuries that were mutually beneficial for states and firms alike. As an integral part of Early Modern societies, economic and business history are bound to become

11 Reinert, S.A., and R. Fredona. "Merchants and the Origins of Capitalism." Working Paper 18-021, Harvard Business School (2017), http://www.hbs.edu/faculty/publication\%20 files/18-021_b3b67ba8-2fc9-4agb-8955-67od5f491939.pdf (accessed 17 December 2019); Prakash, O. "International Consortiums, Merchant Networks and Portuguese Trade in Asia in the Early Modern Period." Panel Session 37, xIV International Economic History Congress, Helsinki, 21-25 August 2006, http://www.helsinki.fi/iehc20o6/papersi/Prakash. pdf (accessed 17 December 2019).

12 Smith, E. "Mercantile Diplomacy: Corporations, States and International Negotiation." In Stuart Marriage Diplomacy: Dynastic Politics in their European Context, 1604-1630, eds. V. Caldari and S.J. Wolfson (London: Boydell and Brewer, 2018), 125-38; Leira H., and I.B. Neumann. "Judges, Merchants and Envoys: The Growth and Development of the Consular Institution." Panel Session FB44, $47^{\text {th }}$ Annual IsA Convention, San Diego, 2006, https:// www.peacepalacelibrary.nl/ebooks/files/371402476.pdf (accessed 17 December 2019). 
part of what John Watkins has coined "a new diplomatic history of Medieval and Early Modern Europe."13

13 Watkins, J. “Toward a New Diplomatic History of Medieval and Early Modern Europe." Journal of Medieval and Early Modern Studies 38 (1) (2008), 1-14. 